\title{
Discovery Learning: Development of a Unique Active Learning Environment for Introductory Chemistry
}

\author{
Laura E. Ott \\ leott@umbc.edu \\ Tara S. Carpenter \\ $\mathrm{UMBC}$ \\ carpent@umbc.edu \\ Diana S. Hamilton \\ $\mathrm{UMBC}$ \\ hamilton@umbc.edu \\ William R. LaCourse \\ $\mathrm{UMBC}$ \\ lacourse@umbc.edu
}

University of Maryland, Baltimore County (UMBC)

\begin{abstract}
It is well established that active learning results in greater gains in student conceptual knowledge and retention compared to traditional modes of teaching. However, active learning can be very difficult to implement in a largeenrollment course due to various course and institutional barriers. Herein, we describe the development and implementation of Discovery Learning, a novel active learning discussion/recitation for a large enrollment general chemistry course. Drawing on the very successful cooperative learning pedagogies ProcessOriented Guided Inquiry Learning (POGIL) and Student-Centered Active Learning Environment with Upside-down Pedagogies (SCALE-UP), Discovery Learning involves students working in self-managed teams on inquiry problems in a unique learning environment, the Chemistry Discovery Center. In this case study, we will describe the design and implementation of Discovery Learning and report data on its successes, which include increased student performance and retention.
\end{abstract}

Keywords: active learning, chemistry, recitation, technology, Process-Oriented Guided Inquiry Learning (POGIL), Student-Centered Active Learning Environment with Upside-Down Pedagogies (SCALE-UP).

A recent report by the President's Council of Advisors on Science and Technology (PCAST) demonstrated that one of the top factors for students not persisting in the science, technology, engineering, and mathematics (STEM) field was uninspiring introductory courses (President's Council of Advisors on Science and Technology, 2012). This highlights the importance of engaging STEM students in active learning, which increases students' conceptual knowledge and attitudes towards learning, while also decreasing attrition rates (Bullard, Felder, \& Raubenheimer, 2008; Freeman et al., 2014; National Research Council, 2015).

Active learning has been shown to be effective across all STEM disciplines and class sizes, although the greatest impact is in courses with fewer than 50 students (Freeman et al., 2014). While 
various active learning strategies can be employed to actively engage students in large-enrollment courses (Beichner et al., 2007; Cooper, 1995; Hodges, 2015; National Science Teachers Association, 2002), large-enrollment courses traditionally involve students learning content passively from lecturing faculty members. This is often due to the challenges of implementing active learning in a large-enrollment course, which include large numbers of students and the layout of a typical lecture hall.

To help reinforce classroom learning, most large-enrollment STEM courses are associated with a recitation section. In many instances, recitations take a similarly passive approach, during which teaching assistants (TAs) review course material without actively engaging students. Recently, however, some STEM courses have redesigned their recitation sections to include active learning, which increased student performance and retention (Finkelstein \& Pollock, 2005; Pollock \& Finkelstein, 2008; Watt et al., 2014). For example, increased student performance was observed when a group problem solving approach was adopted in an introductory chemistry recitation (Mahalingam, Schaefer, \& Morlino, 2008).

Herein, we describe the design and implementation of a novel general chemistry discussion/recitation section called Discovery Learning. Discovery Learning is a unique adaptation of two very effective active learning pedagogies: Process-Oriented Guided Inquiry Learning (POGIL; Moog et al., 2009) and Student Centered Active Learning Environment with Upside-down Pedagogies (SCALE-UP; Beichner et al., 2007). Discovery Learning was implemented in Principles of Chemistry I (CHEM 101) at the University of Maryland, Baltimore County (UMBC) in 2005 as a means to increase student performance and retention. Specifically, Discovery Learning involves students working in small groups with defined roles on guided inquiry activities in a unique learning environment, the Chemistry Discovery Center.

\section{CHEM 101 Before Implementation of Discovery Learning}

Many students besides chemistry majors enroll in introductory chemistry courses at most institutions (American Chemical Society, 2005). At UMBC", CHEM 101 is a required or recommended course for most STEM majors, including chemistry, biochemistry, biology, physics, computer engineering, mechanical engineering, chemical engineering, environmental science, psychology, and pre-professional programs such as pre-pharmacy or pre-dentistry. CHEM 101 is also a non-lab science course option for students needing to complete one of such courses as part of UMBC's general education requirements. Further, CHEM 101 is a pre-requisite for any student wanting to take Principles of Chemistry II (CHEM 102) or Introductory Chemistry Lab (CHEM 102L). CHEM 102 and CHEM 102L are also required or recommended for most STEM majors, with CHEM 102L counting as a science laboratory course, another general education requirement.

Prior to the implementation of Discovery Learning, CHEM 101 consisted of three 50minute lectures and a single 50-minute recitation each week. The lectures were led by faculty members and were taught in a traditional lecture setting, with approximately 300-350 students in each lecture. The recitations were led by graduate TAs, who reviewed homework and exam questions and demonstrated problem solving in a didactic format. There were approximately 5080 students in each recitation and students took a quiz on relevant course content at the end of each session. The average recitation quiz score was weighted the same as a mid-term exam in the class after the two lowest quiz grades were dropped from the quiz average. Course grades were based on three mid-term grades, the average recitation quiz grade, and the final exam, which was

Journal of the Scholarship of Teaching and Learning, Vol. 18, No. 4, December 2018. josotl.indiana.edu 
weighted the same as two mid-term exams. The lowest exam score was dropped such that the final grade in the course was based on five out of the six assessments, which were weighted equally.

The main influence for the development of Discovery Learning was the observation that student performance and retention were dropping. This observation was made independent of the course instructor, the utilization of streamlined material and uniform content, or the use of exam testing banks. A review of available institutional records revealed that approximately $25 \%$ of students received a failing grade (D or F) in CHEM 101 in the fall semesters during the three years prior to the implementation of Discovery Learning (2002-2004). Further, an average of $6.9 \%$ of students withdrew from the class during this period. This high number of failing grades or withdrawals resulted in an increasing sense of frustration among students, with CHEM 101 anecdotally described as a "weed out course".

Another reason for the development of Discovery Learning arose from the observation that students' lecture attendance was decreasing. Attendance to recitation, however, was mandatory and forced through the administration of quizzes at the end of each session. That being said, many students did not use recitation effectively by using the session to clarify course content. The students that did use the recitations effectively were primarily the high-achieving students.

\section{Pedagogical Framework for Discovery Learning}

Discovery Learning is founded on cooperative learning, where students work in structured small groups on activities designed to advance their understanding of material. Cooperative learning environments have been described extensively and are characterized by positive interdependence, individual accountability, face-to-face interaction, appropriate use of interpersonal skills, and regular self-assessment of group functioning (Johnson, Johnson, \& Smith, 2010; Johnson, Johnson, \& Smith, 1991). Advantages of cooperative learning include demonstrated gains in conceptual knowledge and knowledge retention, students taking responsibility for and becoming more actively engaged in their learning, developing higher-order reasoning skills, and decreasing student attrition while increasing student satisfaction towards learning and the subject (Cooper, 1995; Johnson \& Johnson, 1989). Cooperative learning is particularly advantageous for largeenrollment courses, as it increases classroom communication and participation while also maximizing student-to-student and student-to-instructor interactions (Cooper, 1995). Given its effectiveness, many active learning pedagogies are based on cooperative learning. These pedagogies include POGIL and SCALE-UP. POGIL is a direct influence on Discovery Learning, whereas SCALE-UP has parallels to the unique environment where Discovery Learning occurs, the Chemistry Discovery Center.

\section{Process-oriented guided inquiry learning (POGIL)}

POGIL, which was initially developed for general chemistry curricula, is theoretically based on both the learning cycle (Abraham, 2005; Cracolice, 2009; Lawson, 1995, 1999) and social constructivism (Bodner, Klobuchar, \& Geelan, 2001; Bodner, 1986; Eberlein et al., 2008). Students work in teams of 3-4 to complete carefully crafted guided-inquiry activities that walk them through the learning cycle (Eberlein, et al., 2008; Hanson, 2006b; Moog, et al., 2015; Moog et al., 2009). Teams are self-managed by students enacting assigned roles, which are thought to promote team interdependence and equal participation (Johnson \& Johnson, 1989; Johnson et al., 1991). The roles within a team rotate regularly and new teams are formed periodically within a

Journal of the Scholarship of Teaching and Learning, Vol. 18, No. 4, December 2018. josotl.indiana.edu 
given course. Working in teams is emphasized in POGIL because of the development of crucial process skills, such as information processing, critical and analytical thinking, problem solving, communication, teamwork, management, and assessment (Hanson, 2006b).

Hanson (2006b) describes a variety of ways to implement POGIL. In the classic implementation, POGIL activities serve as an introduction to topics and students complete textbook reading and practice problems afterwards. The instructor does not lecture and instead circulates throughout the classroom, only intervening if necessary. Specialized learning spaces are not required, as POGIL activities have been implemented in small (Farrell, Moog, \& James N. Spencer, 1999; Hinde \& Kovac, 2001) and large (Lewis \& Lewis, 2005; Moog et al., 2009) class environments, as well as in recitations (Hanson \& Wolfskill, 2000). POGIL has also been used for laboratory instruction (Hunnicutt, Grushow, \& Whitnell, 2015). Within the chemistry field, POGIL curricula have been created for general chemistry (Garoutte \& Mahoney, 2015), organic chemistry (Ruder, 2015), biochemistry (Loertscher \& Minderhout, 2011), physical chemistry (Spencer, Moog, \& Farrell, 2012), and analytical chemistry (Lantz \& Cole, 2014a, 2014b). POGIL curricula have also been created for other STEM disciplines including biology (Trout, 2012a, 2012b), anatomy and physiology (Brown, 2015; Jensen, 2014), engineering (Douglas, 2014), and introductory calculus (Straumanis et al., 2013).

The POGIL approach has been very effective at increasing student performance, conceptual knowledge, and retention (Farrell et al., 1999; D. Hanson \& Wolfskill, 2000; Lewis \& Lewis, 2005). Further, POGIL implementation results in students advancing key process skills, such as critical thinking, self-directed learning, teamwork, communication, and management (Hanson, 2006b; Minderhout \& Loertscher, 2007).

\section{Student-Centered Active Learning Environment with Upside-down Pedagogies (SCALE-UP)}

SCALE-UP is a large-course adaptation of small physics studio courses that have demonstrated gains in student conceptual knowledge compared to traditional course formats (Hoellwarth, Moelter, \& Knight, 2005; Wilson, 1994). The physical layout of a SCALE-UP classroom is key, as it fosters student-to-student and student-to-instructor interactions, which are key factors to student success (Astin, 1993; Johnson et al., 1991). Specially designed tables installed in a SCALE-UP classroom allow for teams to work effectively and instructors to move easily around the room to assist teams when needed. Each team consists of three students and as in POGIL, assigned roles are used (Beichner et al., 2007; Gaffney, Richards, Kustusch, L. Ding, \& Beichner, 2008). There are typically multiple teams at each table, which allows for either individual or multiple team interactions (Gaffney et al., 2008). The SCALE-UP classroom incorporates specially placed projectors and technology that allow for the display of student work. Whiteboards, which promote collaboration (Knaub, Foote, Henderson, Dancy, \& Beichner, 2016), are available for students to work problems and display their findings to their peers and instructors. Each team has access to its own Internet-connected computer to complete interactive modules or electronic laboratory activities (Beichner, 2008, 2014; Beichner et al., 2007; Gaffney et al., 2008). For physics, SCALE-UP sessions are a hybrid of lecture and laboratory, during which teams have access to lab equipment. A typical SCALE-UP session is staffed by the course instructor and multiple teaching assistants (Beichner et al., 2007; Gaffney et al., 2008).

SCALE-UP physics has been implemented at numerous institutions and a comparison of SCALE-UP to traditional teaching methods has revealed multiple student gains (Beichner, 2008; Beichner et al., 2007; Gaffney et al., 2008). Specifically, SCALE-UP resulted in increased

Journal of the Scholarship of Teaching and Learning, Vol. 18, No. 4, December 2018. josotl.indiana.edu 
performance on validated concept inventories compared to passive lecture instruction. Interestingly, students in the top-third of classes had the greatest conceptual gains and it is hypothesized that this is the result of these students teaching others in the SCALE-UP environment. Further, SCALE-UP physics instruction statistically reduces failure rates, particularly for female and minority students, and increases student attendance, attitudes, and problem-solving abilities compared to traditional lecture. Besides physics, SCALE-UP has also been implemented in other STEM disciplines, such as biology (Brooker, et al., 2012; Mears, 2015) and chemistry (Oliver-Hoyo, Allen, Hunt, Hutson, \& Pitts, 2004; Weaver \& Sturtevant, 2015), with noticeable gains in student performance observed.

\section{Description of Discovery Learning}

At UMBC, Discovery Learning sessions are a course requirement for CHEM 101 and CHEM 102. Each Discovery session can accommodate 72 students. A single doctoral level instructor facilitates all Discovery Learning sessions and works closely with other course (i.e., lecture) instructors to ensure alignment of topics covered. Discovery sessions are held Monday through Thursday and last one hour and 50 minutes. Refer to Figure 1 for a weekly Discovery Learning schedule during a typical fall semester, which is the semester where the majority of students enroll in CHEM 101.

\begin{tabular}{|c|c|c|c|c|c|}
\hline Time & Monday & Tuesday & Wednesday & Thursday & Friday \\
\hline $8 \mathrm{AM}$ & & \multirow{2}{*}{ CHEM 101} & \multirow{2}{*}{ CHEM 102} & \multirow{2}{*}{ CHEM 101} & \\
\hline $9 \mathrm{AM}$ & & & & & \\
\hline $10 \mathrm{AM}$ & \multirow{2}{*}{ CHEM 101} & \multirow{2}{*}{ CHEM 102} & \multirow{2}{*}{ CHEM 101} & \multirow{2}{*}{ CHEM 102} & \\
\hline $11 \mathrm{AM}$ & & & & & \\
\hline $12 \mathrm{PM}$ & & & LA meeting & & LA meeting \\
\hline $1 \mathrm{PM}$ & \multirow[b]{2}{*}{ CHEM 101} & \multirow[b]{2}{*}{ CHEM 101} & \multirow[b]{2}{*}{ CHEM 101} & \multirow{2}{*}{ CHEM 101} & \\
\hline $2 \mathrm{PM}$ & & & & & \\
\hline 3 PM & \multirow{2}{*}{ CHEM 101} & & \multirow{2}{*}{ CHEM 101} & & \\
\hline 4 PM & & \multirow{2}{*}{ CHEM 101} & & \multirow{2}{*}{ CHEM 101} & \\
\hline $5 \mathrm{PM}$ & \multirow{2}{*}{ CHEM 101} & & & & \\
\hline $6 \mathrm{PM}$ & & & & & \\
\hline 7 PM & & & & & \\
\hline
\end{tabular}

Figure 1. Typical weekly Discovery session schedule for the fall semester.

In addition to the faculty member, two to four undergraduate learning assistants (LAs) are present for each Discovery Learning session. The LAs circulate around the room and assist students when needed. The LAs are trained in facilitating cooperative learning environments prior to the start of the semester via roleplaying and modeling scenarios. Returning Discovery LAs also 
mentor new LAs during the semester to help the new LAs transition from being a student to a facilitator in the Discovery Learning environment. Additionally, the faculty member meets with the LAs weekly to review relevant material for upcoming sessions. In addition to undergraduate LAs, a small number of graduate TAs support Discovery Learning by grading and providing feedback on Discovery documents. It should be noted that in the early years of Discovery Learning, graduate TAs were used in both Discovery Learning sessions and for the development and grading of Discovery documents. The switch to undergraduate LAs during Discovery sessions was made in the later years of Discovery Learning, as it was found to be more effective and economical.

\section{Layout of the Chemistry Discovery Center}

It is well established that for the implementation and sustainment of active learning pedagogies, the thoughtful design of the physical classroom needs to be highly considered (Beichner et al., 2007; Cotner, Loper, Walker, \& Brooks, 2013; Knaub et al., 2016; Whiteside, Brooks, \& Walker, 2010). Discovery Learning occurs in a special environment, called the Chemistry Discovery Center, which has parallels to the SCALE-UP classroom (Beichner et al., 2007; Gaffney et al., 2008). The Chemistry Discovery Center contains 18 stations, each named after an element that can accommodate a team of four students. The stations are organized such that there are 6 larger groups (or triads), each consisting of three teams. This allows for multiple teams to interact during aspects of a Discovery session. Each station contains a table with four chairs, a computer with a keyboard, mouse, two monitors, and a calculator. Two monitors are at each table so that each student can easily view the Discovery documents, which are electronic. Each station also includes a white board with markers and a binder with relevant handouts and charts. It should be noted that the Chemistry Discovery Center is otherwise completely paperless, with students working exclusively on electronic documents. Scrap paper is strictly prohibited and instead, teams must use their whiteboards to work problems. Strict whiteboard usage promotes collaboration (Knaub et al., 2016) and allows the instructor and TAs to gauge a team's understanding of the material and provide clarification if necessary. At the back of the room, there is an instructor's desk that is outfitted with a computer with SchoolVue Classroom Management Software (CrossTec Corporation, Boca Raton, FL) installed for deployment of Discovery Learning documents and control of station computers. SchoolVue software also allows for the instructor to keep track of student progress and ensure that teams are staying on task. The Chemistry Discovery Center also contains a side room for TA meetings and trainings. Refer to Figure 2 and 3 for a diagram and pictures of the Chemistry Discovery Center layout, respectively. 


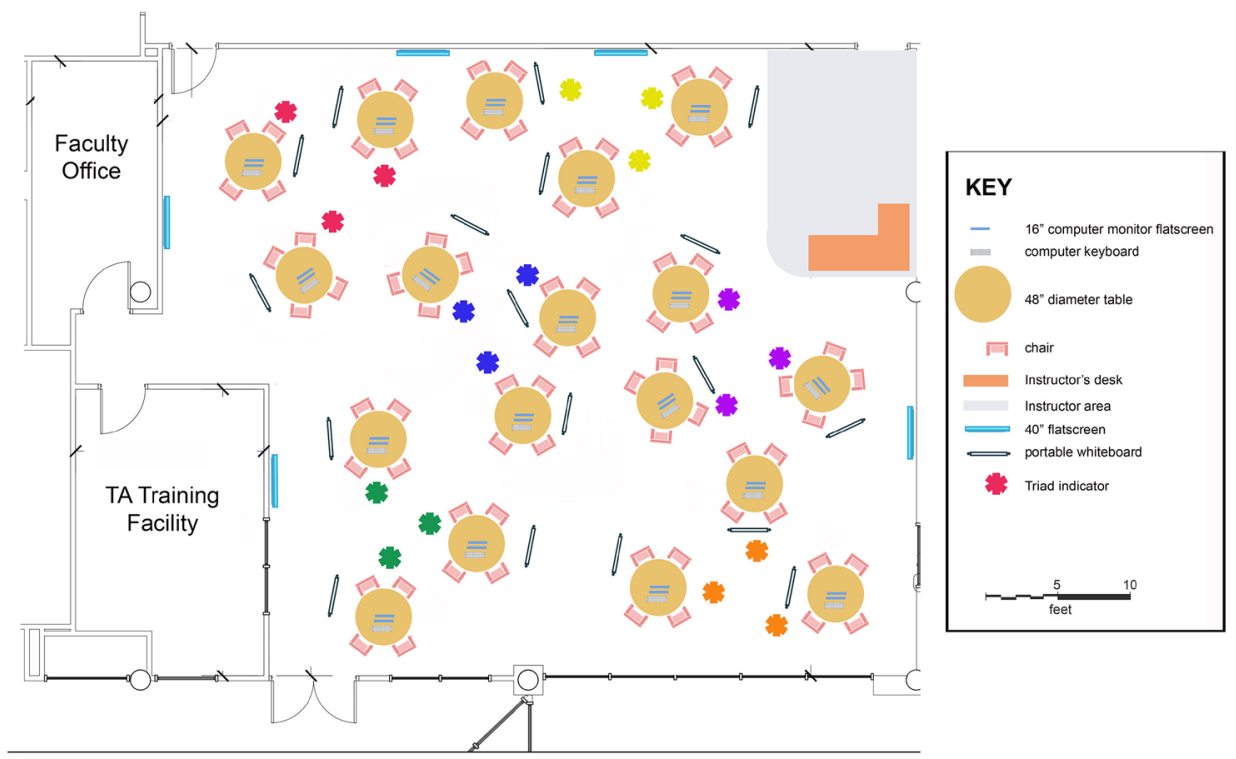

Figure 2. Layout of the Chemistry Discovery Center.

A
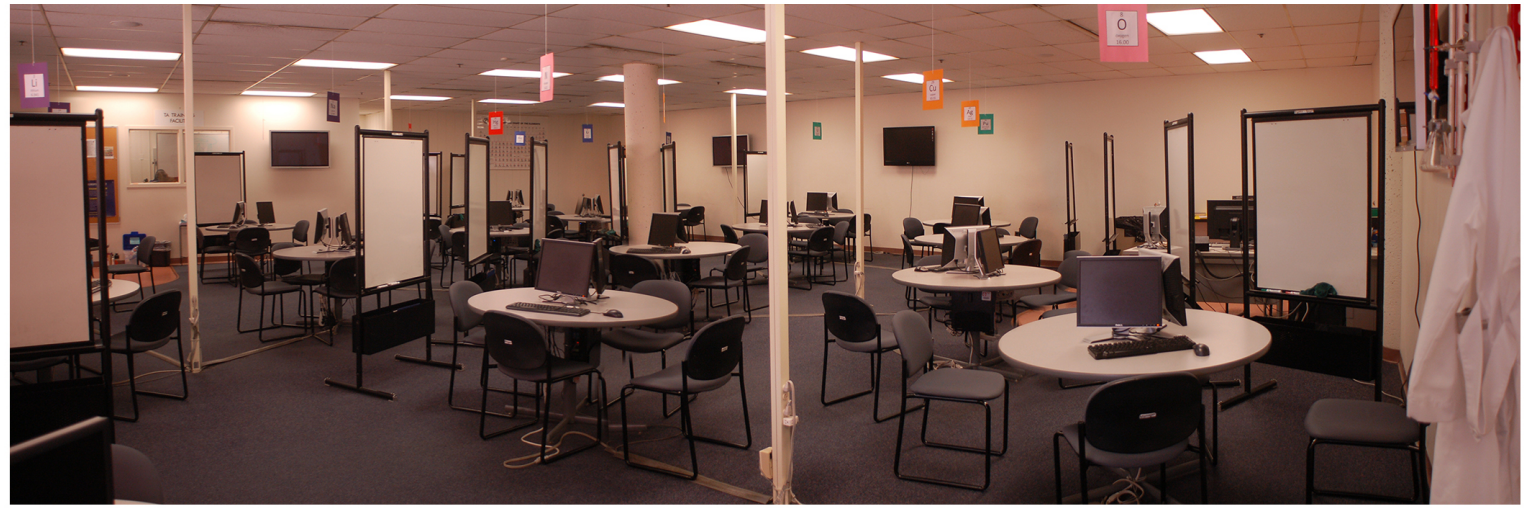

B

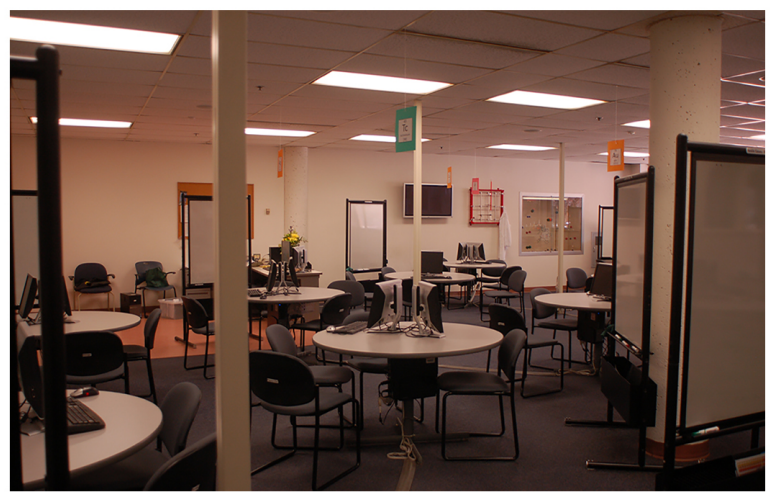

C

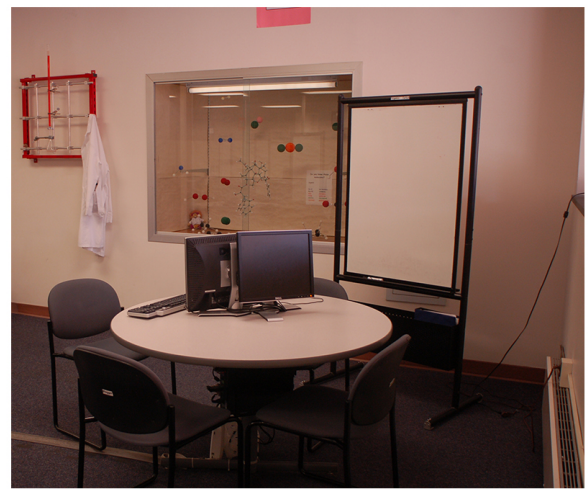

Figure 3. Pictures of the Chemistry Discovery Center. A, Panoramic view of the Chemistry Discovery Center; B, View of the station triad layout; C, Close up view of a single station. 


\section{Team Roles}

Students work in teams of four during Discovery Learning, with each member of the team assigned a specific role to enact. Roles that students enact are rotated week to week and sometimes within a single session for variety. Teams are randomly reassigned every four weeks throughout the semester, typically after every team member has experienced each role. The roles used in Discovery Learning include Manager, Blogger, Scribe, and Researcher, with a description of each role found in the Discovery syllabus provided to students (syllabus can be provided upon request). Teams must write which team member is enacting each role on the whiteboard and team members must sit in specific chairs at the station based on their assigned role.

The Manager serves as the team leader, ensures that the team stays on task, and that each member fulfills their assigned role. Further, the Manager is the spokesperson for the team and is responsible for the condition of the team's station and equipment. The Researcher is the member of the team who operates the calculator and looks up relevant information in the station reference binder. The Scribe is the person who writes on the whiteboard. Finally, the Blogger is the record keeper for the team and types all of the answers onto the Discovery documents that are deployed to the team's station using SchoolVue software.

\section{Discovery Learning Documents}

During Discovery Learning, students work on specially crafted guided inquiry documents that are similar to available POGIL documents (Hanson, 2006a; Moog \& Farrell, 2002). Discovery documents are generated in Microsoft Word and contains explicitly stated student learning goals as well as skills that students will acquire from the session. Further, the documents contain a brief description of key concepts followed by a series of specially crafted questions that sometimes involve students exploring a model or data in the form of a table or chart. Unique "Did You Know?" sections are found in the documents that provide meaningful, fun, and/or historical facts relating to the concepts being discovered. The documents end with an "Apply Your Knowledge" section, where students have to apply what they have learned to new situations. The course instructor and a cadre of graduate teaching assistants update the documents each semester and sample Discovery Learning documents for CHEM 101 can be made available upon request.

\section{Discovery Learning Sessions}

Discovery Learning sessions are one hour and 50 minutes and teams are allowed to take one sevenminute break during their Discovery session at a time that is agreed upon by all team members. At the start of a Discovery session, students refer to a bulletin board at the front of the room for station and role assignments. As mentioned above, each member of the team has an assigned chair based on his or her role. The team's Manager will fill out the Manager's Contract (Appendix A), which is designed to hold students accountable for the team's conduct and proper use of equipment in the Chemistry Discovery Center. The Manager's Contract is collected by the instructor at the end of the session and is used to determine whether any points should be deducted for rule infractions. This ultimately gets at one of the goals of Discovery Learning, which is to instill in students that learning takes focus and discipline.

The Blogger will log onto the computer and access the first Discovery document that has been deployed to team stations. A typical Discovery session includes students completing multiple

Journal of the Scholarship of Teaching and Learning, Vol. 18, No. 4, December 2018. josotl.indiana.edu 
documents, which are deployed to station computers one at a time. The Discovery instructor tracks students' progress and determines when it's appropriate to deploy new documents. Students are not expected to complete all of the presented documents during a Discovery session, but instead to work through them at a pace appropriate for the team's understanding. Students are encouraged to email the documents to themselves for review and optional completion outside of class. While teams are working on the documents, the Discovery instructor and TAs circulate throughout the room and assist as needed.

Occasionally, Discovery sessions will involve a competitive Challenge, which typically occur at the end of a session as review for mid-semester and final exams. During a Challenge, the instructor deploys a difficult multistep question and the team within each triad that first answers the question completely and correctly receives a bonus point for the Discovery Learning session. Afterwards, the instructor will review the question so that win or lose, all students benefit.

Depending on when Discovery sessions occur during the week, students are sometimes introduced to concepts in Discovery prior to lecture, whereas other times students are introduced to concepts in lecture before Discovery. This is different from the classic implementation of POGIL, where POGIL is the students' first exposure to the material (Moog et al., 2015).

\section{Grading of Discovery Learning}

Each Discovery session is worth 20 points, with document responses accounting for 10 points and participation and role performance accounting for the additional 10 points. As mentioned above, many teams do not finish the documents during a typical Discovery session. Thus, the level of completion used as a starting point for grading is based on the average pace of the class, which is determined by the instructor monitoring team progress. Graduate TAs conduct grading of the documents and document keys are posted on the course learning management system for students to compare their answers to correct responses. Participation and role performance is assessed based on instructor and TA observations. On-time attendance is required, with students being deducted points for tardiness. Further, unexcused absences also result in a deduction from the student's overall course grade, with greater than five unexcused absences to Discovery resulting in a nearautomatic failure of the course. These strict attendance policies were enacted to ensure accountability and appropriate team interactions.

In 2005, when Discovery Learning was implemented, CHEM 101 consisted of three midsemester exams and a final exam, which was equivalent to two mid-semester exams. One of these exams was dropped; with the remaining exams averaged equally and added to the average quiz (100 points) and Discovery grades (50 points). Starting in 2006, Discovery counted as $10 \%$ of students' grades, with exams accounting for $80 \%$ of the grade and quizzes counting for the remaining $10 \%$. This grading scheme stayed relatively consistent during future semesters, with the exception of not dropping any exam grades in 2007 and future semesters.

\section{The Success of Discovery Learning}

Implementation of Discovery Learning is associated with increased student performance in CHEM 101. The $\% \mathrm{DFW}$ rates (grades of D, F, or withdrawal from the course) for CHEM 101 in the years prior to Discovery Learning was significantly higher than in the years after implementation (Figure 4). The decrease in the \%DFW rates associated with Discovery Learning correlates with a dramatic increase in the number of students who passed CHEM 101 (grade of C or above), with no alteration

Journal of the Scholarship of Teaching and Learning, Vol. 18, No. 4, December 2018. josotl.indiana.edu 
to the academic rigor of the course (Table 1). This increase in grades also occurred independent of the fact that the grade cut offs had been slowly increased over this time period. For example, in 2004 a student who earned a $79.6 \%$ or above in CHEM 101 received an A, whereas in 2005 a minimum grade of $81.3 \%$ resulted in an $\mathrm{A}$.

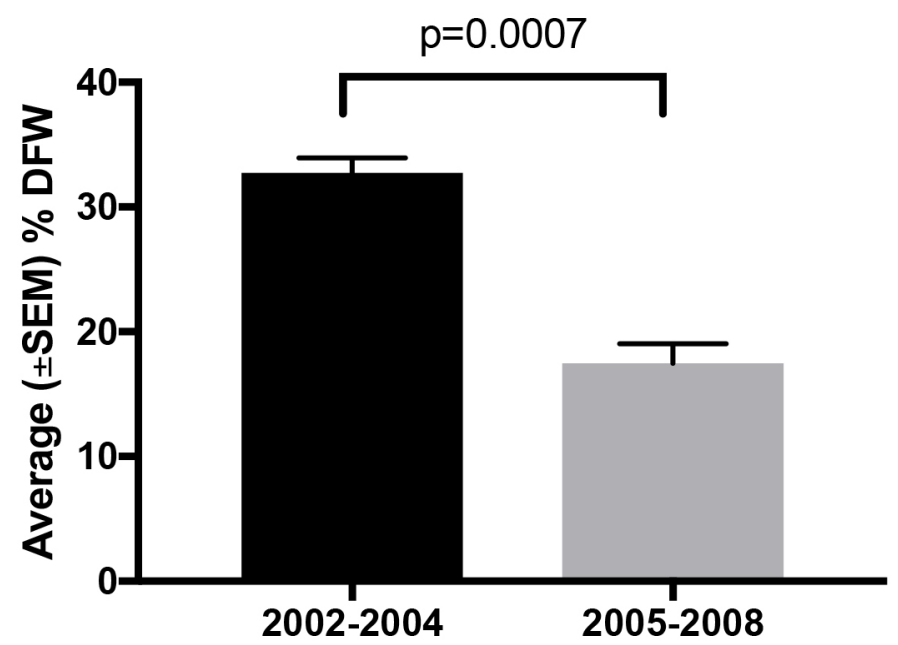

Figure 4. \% DFW rates for the years before (2002-2004) and after (2005-2008) Discovery Learning. Data is reported as average \pm standard error of the mean and data was analyzed with an unpaired t-test using GraphPad Prism (version 7.0b).

Table 1. CHEM 101 grades before (2002-2004) and after (2005-2008) the implementation of Discovery Learning

$\begin{array}{lllllll}\text { Year } & \text { A } & \text { B } & \text { C } & \text { D } & \text { F } & \text { W } \\ 2002 & 9.9 \% & 19.1 \% & 34.1 \% & 19.0 \% & 6.8 \% & 6.9 \% \\ 2003 & 6.6 \% & 16.7 \% & 42.6 \% & 19.5 \% & 5.7 \% & 5.3 \% \\ 2004 & 10.4 \% & 19.0 \% & 31.0 \% & 17.5 \% & 7.8 \% & 9.3 \% \\ 2005 & 15.9 \% & 25.1 \% & 40.6 \% & 8.3 \% & 3.1 \% & 4.0 \% \\ 2006 & 17.4 \% & 23.9 \% & 37.0 \% & 10.6 \% & 5.1 \% & 4.3 \% \\ 2007 & 24.8 \% & 22.3 \% & 30.0 \% & 10.1 \% & 6.7 \% & 3.9 \% \\ 2008 & 26.3 \% & 23.5 \% & 35.2 \% & 5.5 \% & 5.7 \% & 3.1 \%\end{array}$

A comparison of comprehensive final exam scores during the fall 2004 (pre-Discovery) and fall 2005 (first semester of Discovery) semesters of CHEM 101 reveal a modest, yet statistically significant, increase in student learning (Figure 5). The average final exam score in fall 2004 was $55.8 \pm 0.9 \%(n=574)$, while the final exam score in the fall of 2005 was $58.7 \pm 0.9 \%$ $(n=558)$. It should be noted that the final exam covered the same material both semesters. 


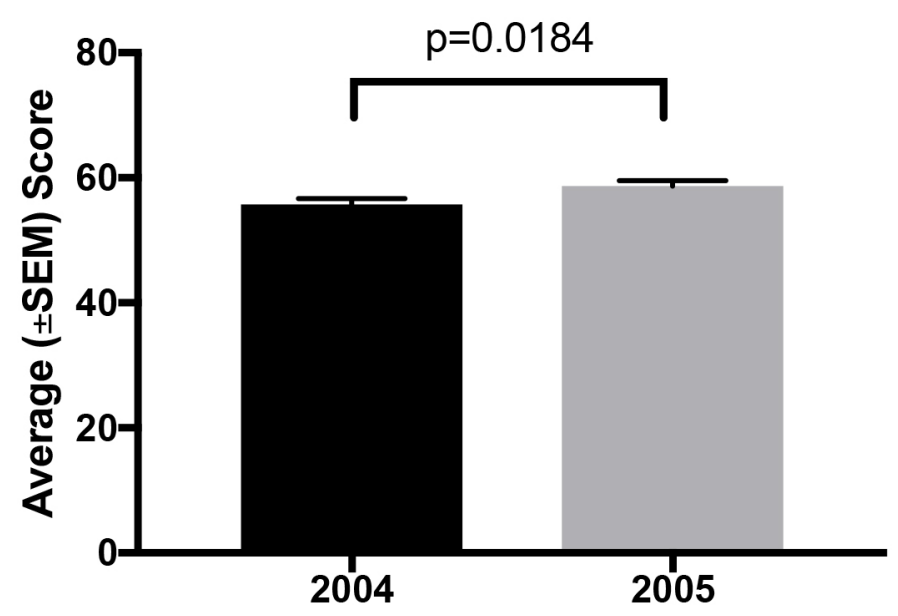

Figure 5. Discovery Learning results in increased CHEM 101 final exam performance. In the fall 2004 semester (pre-Discovery), there were 574 students. In the fall 2005 semester, which is the first semester that Discovery Learning was implemented, there were 558 students. Data is reported as average \pm standard error of the mean and data was analyzed with an unpaired t-test using GraphPad Prism (version 7.0b).

The inclusion of Discovery Learning was also associated with the number of CHEM 101 students who went on to enroll in CHEM 102 in the subsequent semester. Prior to Discovery Learning, the average number of fall CHEM 101 students who enrolled CHEM 102 during the following spring semester was $45.7 \pm 10.0 \%$. In contrast, the retention of students from CHEM 101 into CHEM 102 after the initiation of Discovery Learning was $55.8 \pm 3.2 \%$.

\section{Retention and Graduation of Chemistry Majors}

In addition to increased student performance, Discovery Learning was also associated with an increased retention of chemistry majors. Within the Department of Chemistry and Biochemistry there are two majors: chemistry (B.S. or B.A.) and biochemistry and molecular biology (B.S). The majority of traditional, first year (freshman) majors in the Department take CHEM 101 and 102 during their first year. A review of institutional records revealed that the implementation of Discovery Learning resulted in an increased one-year retention of majors within the Department of Chemistry and Biochemistry (Table 2). Institutional records also revealed an increased retention rate of majors within the Department at later time points. This suggests that Discovery Learning may have provided increased conceptual understanding and retention of foundational knowledge to students within the Department of Chemistry and Biochemistry to help them excel in upper level coursework. Interestingly, Discovery Learning also correlated with increased 4-year and 5-year graduation rates within the Department of Chemistry and Biochemistry (Table 3). 
Ott, Carpenter, Hamilton and LaCourse

Table 2. One-year retention rates (average \pm standard deviation) of students in the Department of Chemistry and Biochemistry before and after the implementation of Discovery Learning

$\begin{array}{lll}\text { Major } & \text { Pre-Discovery (2002-2004) } & \text { Post-Discovery (2005-2008) } \\ \text { All majors } & 86.9 \pm 5.7 \% & 91.2 \pm 3.0 \% \\ \text { Chemistry majors } & 81.9 \pm 4.50 \% & 89.8 \pm 2.4 \% \\ \text { Biochemistry majors } & 87.2 \pm 5.7 \% & 91.7 \pm 3.7 \%\end{array}$

Table 3. Four-year and five-year graduation rates (average \pm standard deviation) for students in the Department of Chemistry and Biochemistry before and after the implementation of Discovery Learning

$\begin{array}{lll}\text { Graduation Rate } & \text { Pre-Discovery (2002-2004) } & \text { Post-Discovery (2005-2008) } \\ \text { 4-year } & 42.6 \pm 8.7 \% & 44.8 \pm 3.5 \% \\ \text { 5-year } & 58.2 \pm 10.3 \% & 64.8 \pm 5.8 \%\end{array}$

Retention of Non-Chemistry STEM Majors

At UMBC, CHEM 101 is also populated by biology, engineering (chemical, computer, and mechanical), environmental science, physics, and psychology majors. Interestingly, implementation of Discovery Learning also correlated with an increased one-year retention rate of most non-chemistry STEM majors (Table 4). This was particularly noticeable in biology, engineering, and environmental science majors. Given that CHEM 101 is often a first year foundational course for STEM majors, these data imply that Discovery Learning correlates to the increased retention of non-chemistry majors. It should be noted, however, that other factors specific to the students' major (such as Departmental curricular changes) might have also attributed to the increased one-year retention of non-chemistry majors.

Table 4. One-year retention rates (average \pm standard deviation) of non-chemistry majors before and after the implementation of Discovery Learning

$\begin{array}{lll}\text { Major } & \text { Pre-Discovery (2002-2004) } & \text { Post-Discovery (2005-2008) } \\ \text { Biology } & 86.2 \pm 3.2 \% & 90.2 \pm 1.6 \% \\ \text { Engineering } & 80.1 \pm 1.1 \% & 86.3 \pm 2.1 \% \\ \text { Environmental science } & 82.6 \pm 15.1 \% & 90.3 \pm 11.5 \% \\ \text { Physics } & 87.3 \pm 9.1 \% & 80.9 \pm 8.3 \% \\ \text { Psychology } & 77.0 \pm 3.6 \% & 86.5 \pm 4.5 \%\end{array}$

\section{Discussion}

Discovery Learning is a highly structured, cooperative learning environment with mandated attendance and strictly enforced rules. The structure was put in place as a means for students to take ownership of their learning and dedicate time each week to practice and develop higher-order processing, critical thinking, and problem-solving skills in a cooperative environment. These 
skills, in turn, help students to better grasp conceptual knowledge associated with general chemistry (and other STEM disciplines), clarify misconceptions, and likely contribute to students performing better in the course. This observation is supported by other reports of increased course structure correlating to increased performance (Eddy \& Hogan, 2014; Haak, et al., 2011).

Discovery Learning also emphasizes the development of key process skills, which is common to many cooperative learning pedagogies. In Discovery Learning, students work in selfmanaged teams, which requires effective teamwork, communication, and management skills. Additionally, since students work collaboratively on challenging guided inquiry questions, students in Discovery Learning are provided opportunities to advance their information processing, critical thinking, and problem-solving skills. Development of these skills during Discovery Learning is beneficial to students in introductory chemistry, advanced undergraduate and graduate course work, the workforce, and beyond.

\section{Comparison of Discovery Learning to POGIL and SCALE-UP}

Discovery Learning was largely influenced by POGIL, which was developed about 10 years prior. The similarities between POGIL and Discovery Learning include use of structured teams with assigned roles to foster team interdependence and engaging students in guided inquiry problems designed to help advance their conceptual understanding of material (Eberlein, et al., 2008; Hanson, 2006b; Moog et al., 2015). There are also similarities between POGIL and Discovery Learning documents, as Discovery Learning documents were modeled after available POGIL materials ( Hanson, 2006a; Moog \& Farrell, 2002). Discovery Learning, however, is distinguished from POGIL in multiple ways. First, Discovery Learning is a discussion/recitation that complements traditional lecture while POGIL was designed to replace lectures and is also used for laboratory instruction (Hunnicutt et al., 2015). Given this distinction, POGIL is typically students' first exposure to material, while Discovery Learning could come before or after students are exposed to the material through reading, lecture, or other means. Discovery Learning takes place in a unique environment, the Chemistry Discovery Center, which is a carefully designed active learning space outfitted with unique stations that require teams to work problems collaboratively on a whiteboard and submit answers electronically using a single computer. POGIL, on the other hand, typically involves groups of students working on printed guided inquiry worksheets in a traditional classroom. Therefore, in POGIL, team members may work problems individually, even when structured team interactions are emphasized.

SCALE-UP, however, was not a deliberate influence on Discovery Learning, as the similarities between the two pedagogies were not realized until after the implementation of Discovery Learning. The setup of the SCALE-UP classroom is the biggest influence for the Chemistry Discovery Center, as both are unique, technology-driven, learning environments with specially designed workstations that foster student interaction (Gaffney et al., 2008; Knaub et al., 2016). Teams have access to a single computer and whiteboards to work problems collaboratively in SCALE-UP and Discovery Learning. The major differences between the two environments is that in SCALE-UP, three teams of three students are at a station (Gaffney et al., 2008), while a single team of four students are at a station in Discovery Learning. Thus SCALE-UP fosters both individual and multiple group interactions, while Discovery Learning typically involves only a single group interacting at a time. The only exception to this is during Discovery Challenges, when teams are encouraged to interact with surrounding teams on challenging problems.

Institutionalization of Discovery Learning

Journal of the Scholarship of Teaching and Learning, Vol. 18, No. 4, December 2018. josotl.indiana.edu 
The overwhelming success of Discovery Learning has resulted in it being institutionalized in the two-semester general chemistry sequence at UMBC. Creation of the Chemistry Discovery Center was made possible with the re-purposing of a campus game room. Internal funds were used for renovations to the room and purchasing of equipment and software. The yearly budget for the Chemistry Discovery Center is affordable, especially given that it is mostly a paper-free environment with low printing costs. Further, while the SchoolVue Classroom Management software is used currently, a learning management system (e.g., Blackboard) could be used to distribute and collect Discovery documents electronically. Personnel costs for Discovery Learning include a full-time lecturer and one graduate TA, who is on a teaching assistantship and provided a stipend, health benefits, and tuition. The undergraduate LAs are not paid and instead offered credit for their service.

\section{Adaptation of Discovery Learning}

To date, Discovery Learning has only been implemented in the two-semester introductory general chemistry sequence at UMBC. That being said, given the available POGIL materials, Discovery Learning could easily be adapted for more advanced chemistry or non-chemistry courses (Douglas, 2014; Lantz \& Cole, 2014a, 2014b; Loertscher \& Minderhout, 2011; Ruder, 2015; Spencer et al., 2012; Straumanis et al., 2013; Trout, 2012a, 2012b).

The Chemistry Discovery Center is a key aspect of Discovery Learning, as it is a uniquely designed learning environment that cultivates student engagement and cooperative interactions. We argue that the design and layout of the Chemistry Discovery Center is key to the success and implementation of Discovery Learning at UMBC and this argument is supported by the SCALEUP literature. Specifically, it was found that if an appropriate classroom space can be designed for the implementation of SCALE-UP, the likelihood of SCALE-UP being implemented and sustained at an institution increases (Knaub et al., 2016). This argues the importance of a strategically designed classroom environment for the implementation and sustainment of active learning pedagogies. Regardless, Discovery Learning could be implemented in classrooms that have alterative layouts to the Chemistry Discovery Center as long as the classroom environment is carefully selected for its ability to foster collaborative student interactions and provides access to items such as computers and whiteboards. For example, a SCALE-UP classroom could be a suitable environment for Discovery Learning, given that computers are already available at student workstations and the room is outfitted with whiteboards for teams to work problems collaboratively. However, given that SCALE-UP classrooms typically involve three teams of three at each table, readjustment of the Discovery Learning teams would be needed such that one of the roles is eliminated or combined (e.g., the manager and researcher role could be combined into a single role). Also, extra vigilance ensuring effective individual team interactions would be needed if Discovery Learning were to be implemented in a SCALE-UP classroom given the increased number of teams at each table. Discovery Learning could also be implemented in a traditional classroom laboratory or non-lecture classroom, assuming that each team had access to a computer (such as a personal computer) and whiteboard for teams to work and submit problems. Small, portable whiteboards, chalkboards or large easel pads would be a suitable alternative for individual whiteboards found in the Chemistry Discovery Center. Further, in a traditional, non-lecture classroom, the tables or desks should be modular so that teams can easily form.

Journal of the Scholarship of Teaching and Learning, Vol. 18, No. 4, December 2018. josotl.indiana.edu 


\section{Acknowledgements}

The data presented received exempt review from the UMBC Institutional Review Board (IRB). Appreciation goes to the UMBC Institutional Research, Analysis and Decision Support (IRADS) Office for providing archived institutional records. The authors would like to thank Mr. Tim Ford for his assistance in the creation of Figures 2 and 3.

\section{Appendix}

\section{Appendix 1. Manager's Contract.}

\section{(For full credit - please write legibly)}

As manager, you are responsible for your team, its conduct, and the equipment assigned to you. The following information will ensure that your team is protected from point loss resulting from damaged or stolen equipment and materials. Damage reported by the following group will result in a loss of your team points for the session. This form will also be used to denote team infractions.

\begin{tabular}{|c|c|c|}
\hline I. GROUP DATA & CHEM101 CHEM102 & $\begin{array}{c}\text { FOR INSTRUCTOR USE } \\
\text { ONLY } \\
\end{array}$ \\
\hline Day (circle) & Mon Tues & \\
\hline Time (circle) & $\begin{array}{cccccc}8-10 \mathrm{~A} & 10 \mathrm{~A}-\mathrm{N} & \begin{array}{c}1-3 \mathrm{P} \\
7 \mathrm{P}\end{array} & 3-5 \mathrm{P} & 4-6 \mathrm{P} & 5- \\
& & & & \\
\end{array}$ & \\
\hline \multicolumn{2}{|l|}{ Team Name } & \\
\hline $\operatorname{ROLE}\left(\right.$ at $\left.t_{0}\right)$ & $\begin{array}{l}\text { FULL NAME (list student only if } \\
\text { present) }\end{array}$ & \\
\hline \multicolumn{2}{|l|}{ Manager } & \\
\hline \multicolumn{2}{|l|}{ Blogger } & \\
\hline \multicolumn{2}{|l|}{ Scribe } & \\
\hline Researcher & & \\
\hline
\end{tabular}

\section{CONDITION OF EQUIPMENT (as received):}

\begin{tabular}{|l|c|l|}
\hline \multicolumn{1}{|c|}{ ITEM } & SUGGESTIONS & CONDITION \\
\hline Computer & $\begin{array}{c}\text { present, clean, } \\
\text { working, missing parts, } \\
\text { issues }\end{array}$ & \\
\hline Calculator & present, clean, working & \\
\hline Whiteboard & clean, missing parts & \\
\hline Markers, Eraser & present, usable & \\
\hline
\end{tabular}




\begin{tabular}{|l|c|l|}
\hline Periodic Table & present, good condition & \\
\hline Ballpoint Pen & present, good condition & \\
\hline Binder, Paper Docs & present, good condition & \\
\hline Table & clean, no gum & \\
\hline Chairs & $\begin{array}{c}\text { clean, no gum, labeled, } \\
\text { only 4, in place }\end{array}$ & \\
\hline Miscellaneous & (item dependent) & \\
\hline
\end{tabular}

Team Check: Complying with no gum/food/drink, no cell/texting/devices? YES NO

I, the team manager, hereby acknowledge that the data provided above are accurate and true to the best of my knowledge. I assume responsibility for my team, its conduct, and all assigned equipment.

Current Manager's signature:

date:

III. TEAM INFRACTIONS (for instructor use only):

Cellphone or other device

M B W R $\square$ Misuse of PC

M B

Food, drink, gum, candy etc visible

or in use (-3)

M B W R $\square$ Notes, paper, textbook etc out or in use (-1)

M B W R

Item missing or removed

M B W R $\square$ Early departure

M B W R

PC not logged off at end; or PC

powered off at end (-2)

M B $\square$ Board not erased (-2) M W

Damage or defacement

M B W R $\square$ Other:

M B W R

IV. TEAM STRETCH BREAK (7 min):

\begin{tabular}{|c|c|}
\hline BEGIN TIME & END TIME \\
\hline & \\
\hline
\end{tabular}

\section{ROLE SWITCH (when called):}

Starting Manager to:

Starting Blogger to:

Starting Scribe to:

Starting Researcher to:

VI. MANAGER'S ASSESSMENT (if something changed from initial condition):

\begin{tabular}{|c|c|}
\hline $\operatorname{ITEM}(\mathrm{s})$ & COMMENT \\
\hline & \\
\hline & \\
\hline
\end{tabular}

Journal of the Scholarship of Teaching and Learning, Vol. 18, No. 4, December 2018. josotl.indiana.edu 
VII. GENERAL (optional):

Suggestions, constructive criticism or comments from your group

\section{SIGN OFF}

I, the team manager, hereby acknowledge that data provided above are accurate and true to the best of my knowledge. I assume responsibility for my team, its conduct, and all assigned equipment.

Current Manager's signature:

date:

\section{References}

Abraham, M. R. (2005). Inquiry and the learning cycle approach. In N. J. Pienta, M. M. Cooper, \& T. J. Greenbowe (Eds.), Chemists' guide to effective teaching. Upper Saddle River, NJ: Prentice Hall.

American Chemical Society. (2005). Report on the CPT Survey of 2001-2004 Enrollments in Selected Chemistry Courses. Washington, DC: American Chemical Society.

Astin, A. (1993). What matters in college: Four critical years revisited. San Francisco, CA: Jossey-Bass Publishers.

Beichner, R. J. (2008). The SCALE-UP Project: A student-centered, active learning environment for undergraduate programs. In National Academies of Sciences. Washington, DC. Retrieved from https://www.ncsu.edu/per/byAuthorPubs/beichnerpub.html

Beichner, R. J. (2014). History and evolution of active learning spaces. In Active Learning Spaces: New Directions for Teaching and Learning. San Francisco, CA: Jossey-Bass.

Beichner, R. J., Saul, J. M., Abbott, D. S., Morse, J. J., Deardorff, D. L., Allain, R. J., ... Risley, J. S. (2007). The student-centered activities for large enrollment undergraduate programs (SCALE-UP) project. In E. Redish \& P. J. Cooney (Eds.), Research-Based Reform of University Physics. Retrieved from http://www.per-central.org/items/detail.cfm?ID=4517

Bodner, G., Klobuchar, M., \& Geelan, D. (2001). The many forms of constructivism. Journal of Chemical Education, 78, 1107. doi: 10.1021/ed078p1107.4

Bodner, G. M. (1986). Constructivism: A theory of knowledge. Journal of Chemical Education, 63, 873. doi: 10.1021/ed063p873

Bowen, C. W. (2000). A quantitative literature review of cooperative learning effects on high school and college chemistry achievement. Journal of Chemical Education 77, 116. doi: $10.1021 / \mathrm{ed} 077 \mathrm{p} 116$

Brown, P. (2015). Anatomy \& physiology: A guided inquiry. Hoboken, NJ: Wiley. 
Brooker, R, Matthes, D., Wright, R., Wassenberg, D., Wick, S., \& Couch, B. (2012). SCALEUP in a large introductory biology course. In T. Ferrett, J. Stewart \& W. Schlegel (Eds.) Connected Science: Strategies for Integrative Learning in College. Indiana University Press.

Bullard, L., Felder, R., \& Raubenheimer, D. (2008). Effects of active learning on student performance and retention. In Proceedings of the Annual Conference of the American Society for Engineering Education. Pittsburgh, PA. Retrieved from http://www4.ncsu.edu/unity/lockers/users/f/felder/public/Papers/ASEE08(ActiveLearning ).pdf.

Cooper, M. M. (1995). Cooperative learning: An approach for large enrollment courses. Journal of Chemical Education, 72, 162. doi: 10.1021/ed072p162

Cotner, S., Loper, J., Walker, J. D., \& Brooks, D. C. (2013). Research and teaching: "It's not you, it's the room"--Are the high-tech, active learning classrooms worth it?. Journal of College Science Teaching, 42(6), 82-88.

Cracolice, M. S. (2009). Guided inquiry and the learning cycle. In N. J. Pienta, M. M. Cooper, \& T. J. Greenbowe (Eds.), Chemists' Guide to Effective Teaching (Vol. II). Upper Saddle River, NJ: Pearson.

Douglas, E. (2014). Introduction to materials ccience and engineering: A guided inquiry. Upper Saddle River, NJ: Pearson.

Eberlein, T., Kampmeier, J., Minderhout, V., Moog, R. S., Platt, T., Varma-Nelson, P., \& White, H. B. (2008). Pedagogies of engagement in science. Biochemistry and Molecular Biology Education, 36(4), 262-273. doi: 10.1002/bmb.20204

Eddy, S. L., \& Hogan, K. A. (2014). Getting under the hood: How and for whom does Increasing course structure work? CBE-Life Sciences Education, 13(3), 453-468. doi: 10.1187/cbe.14-03-0050

Farrell, J. J., Moog, R. S., \& James N. Spencer. (1999). A guided-inquiry general chemistry course. Journal of Chemical Education, 76, 570-574. doi: 10.1021/ed076p570

Finkelstein, N. D., \& Pollock, S. J. (2005). Replicating and understanding successful innovations: Implementing tutorials in introductory physics. Physical Review Special Topics - Physics Education Research, 1(1), 010101. doi: 10.1103/PhysRevSTPER.1.010101

Freeman, S., Eddy, S. L., McDonough, M., Smith, M. K., Okoroafor, N., Jordt, H., \& Wenderoth, M. P. (2014). Active learning increases student performance in science, engineering, and mathematics. Proceedings of the National Academy of Sciences, 111(23), 8410-8415. doi: 10.1073/pnas.1319030111

Gaffney, J. D. H., Richards, E., Kustusch, M. B., L. Ding, \& Beichner, R. J. (2008). Scaling up education reform. Journal of College Science Teaching, 37, 48-53.

Garoutte, M. P., \& Mahoney, A. B. (2015). Chemistry: A guided inquiry. Hoboken, NJ: Wiley. Retrieved from http:/www.wiley.com/WileyCDA/WileyTitle/productCd1119046831.html

Haak, D. C., HilleRisLambers, J., Pitre, E., \& Freeman, S. (2011). Increased structure and active learning reduce the achievement gap in introductory biology. Science, 332(6034), 12131216. doi: $10.1126 /$ science. 1204820

Hanson, D. M. (2006a). Foundations of chemistry: Applying POGIL principles (2nd ed.). Lisle, IL: Pacific Crest. 
Hanson, D. M. (2006b). Instructor's guide to Process-Oriented Guided-Inquiry Learning. Lisle, IL: Pacific Crest. Retrieved from https://pogil.org/uploads/media_items/pogil-instructor-sguide-1.original.pdf

Hanson, D., \& Wolfskill, T. (2000). Process workshops - A new model for instruction. Journal of Chemical Education, 77, 120-130. doi: 10.1021/ed077p120

Hinde, R. J., \& Kovac, J. (2001). Student active learning methods in physical chemistry. Journal of Chemical Education, 78, 98-99. doi: 10.1021/ed078p93

Hodges, L. C. (2015). Teaching undergraduate science: A guide to overcoming obstacles to student learning. Sterling, VA: Stylus Publishing.

Hoellwarth, C., Moelter, M., \& Knight, R. (2005). A direct comparison of conceptual learning and problem solving ability in traditoinal and studio style classrooms. American Journal of Physics, 74, 459. doi: http://dx.doi.org/10.1119/1.1862633

Hunnicutt, S. S., Grushow, A., \& Whitnell, R. (2015). Guided-inquiry experiments for physical chemistry: The POGIL-PCL model. Journal of Chemical Education, 92, 262-268. doi: $10.1021 /$ ed5003916

Jensen, M. (2014). POGIL activities for introductory anatomy and physiology courses. Hoboken, NJ: Wiley.

Johnson, D., Johnson, R., \& Smith, K. (1991). Cooperative learning: Increasing college faculty instructional productivity (School of Education and Human Development, ASHE-ERIC Higher Education Report No. 4). Washington, DC: The George Washington University. Retrieved from http://eric.ed.gov/?id=ED343465

Johnson, D. W., \& Johnson, R. (1989). Cooperation and competition: Theory and research. Edina, $\mathrm{MN}$ : Interaction Book Company.

Johnson, D. W., Johnson, R. T., \& Smith, K. A. (1991). Active learning: Cooperation in the college classroom. Edina, MN: Interaction Book Company.

Johnson, D. W., Johnson, R. T., \& Smith, K. A. (2010). Cooperative learning returns to college What evidence is there that it works? Change: The Magazine of Higher Learning, 30(4), 26-35. doi: 10.1080/00091389809602629

Knaub, A. V., Foote, K. T., Henderson, C., Dancy, M., \& Beichner, R. J. (2016). Get a room: the role of classroom space in sustained implementation of studio style instruction. International Journal of STEM Education, 3, 1-22. doi: 10.1186/s40594-016-0042-3

Lantz, J., \& Cole, R. (2014a). Analytical chemistry: A guided inquiry approach instrumental analysis collection. Hoboken, NJ: Wiley.

Lantz, J., \& Cole, R. (2014b). Analytical chemistry: A guided inquiry approach quantitative analysis collection. Hoboken, NJ: Wiley.

Lawson, A. E. (1995). Science teaching and the development of thinking. Boston, MA: Wadsworth Publishing.

Lawson, A. E. (1999). What should students learn about the nature of science and how should we teach it? Journal of College Science Teaching, 28, 401.

Lewis, S. E., \& Lewis, J. E. (2005). Departing from lectures: An evaluation of a peer-led Guided inquiry alternative. Journal of Chemical Education, 82, 135-139. doi: 10.1021/ed082p135

Loertscher, J., \& Minderhout, V. (2011). Foundations of biochemistry (3rd ed.). Lisle, IL: Pacific Crest.

Mahalingam, M., Schaefer, F., \& Morlino, E. (2008). Promoting student learning through group problem solving in general chemistry recitations. Journal of Chemical Education, 85, 1577. doi: $10.1021 /$ ed085p1577 
Mears, S. (2015). Comparison of a traditional teaching model to the SCALE-UP teaching model in undergraduate biology: A mixed method study (Master's Thesis). East Carolina University.

Minderhout, V., \& Loertscher, J. (2007). Lecture-free biochemistry: A Process Oriented Guided Inquiry Approach. Biochemistry and Molecular Biology Education, 35(3), 172-180. doi: 10.1002/bmb.39.

Moog, R. S., Creegan, F. J., Hanson, D. M., Spencer, J. N., \& Straumanis, A. (2009). Process oriented guided inquiry learning. In N. J. Pienta, M. M. Cooper, \& T. J. Greenbowe (Eds.), Chemists' guide to effective teaching (Vol. 2). Upper Saddle River, NJ: Prentice Hall.

Moog, R. S., \& Farrell, J. J. (2002). Chemistry: A guided inquiry (2nd ed.). John Wiley \& Sons, Inc.: Hoboken, NJ.

Moog, R. S., Spencer, J. N., \& Straumanis, A. R. (2015). Process-Oriented Guided Inquiry Learning: POGIL and the POGIL project. Metropolitan Universities, 17(4), 41-52.

National Research Council. (2015). Reaching students: What research says about effective instruction in undergraduate science and engineering. Washington, DC: The National Academies Press.

National Science Teachers Association. (2002). Innovative techniques for large-group instruction. Arlington, VA: NSTA Press.

Oliver-Hoyo, M. T., Allen, D., Hunt, W. F., Hutson, J., \& Pitts, A. (2004). Effects of an active learning environment: Teaching innovations at a research I institution. Journal of Chemical Education, 81, 441-448. doi: 10.1021/ed081p441

Pollock, S. J., \& Finkelstein, N. D. (2008). Sustaining educational reforms in introductory physics. Physical Review Special Topics - Physics Education Research, 4(1), 010110. doi: 10.1103/PhysRevSTPER.4.010110

President's Council of Advisors on Science and Technology. (2012). Engage to Excel: Producing one million additional college graduates with degrees in science, technology, engineering, and mathematics. Washington, DC: Executive Office of the President.

Ruder, S. M. (2015). Organic chemistry: A guided inquiry. Hoboken, NJ: Wiley.

Spencer, J. N., Moog, R. S., \& Farrell, J. J. (2012). Physical chemistry: A guided inquiry Thermodynamics. Hoboken, NJ: Wiley.

Straumanis, A., Beneteau, C., Guadarrama, Z., Guerra, J., \& Lenz, L. (2013). Calculus I: A guided inquiry. Hoboken, NJ: Wiley.

Trout, L. (2012a). POGIL activities for AP biology. Batavia, IL: Flinn Scientific.

Trout, L. (2012b). POGIL activities for high school biology. Batavia, IL: Flinn Scientific.

Watt, J. X., Feldhaus, C. R., Sorge, B. H., Fore, G. A., Gavrin, A. D., \& Marrs, K. A. (2014). The effects of implementing recitation activities on success rates in a college calculus course. Journal of the Scholarship of Teaching and Learning, 14(4), 1-17. doi: 10.14434/josotl.v14i4.12823

Weaver, G. C., \& Sturtevant, H. G. (2015). Design, implementation, and evaluation of a flipped format general chemistry course. Journal of Chemical Education, 92, 1437-1448. doi: 10.1021/acs.jchemed.5b00316

Whiteside, A. L., Brooks, D. C., \& Walker, J. D. (2010). Making the case for space: Three years of empirical research on learning environments. EDUCAUSE Quarterly, 33(3).

Wilson, J. (1994). The CUPLE physics studio. The Physics Teacher, 32, 518. doi: http://dx.doi.org/10.1119/1.2344100

Journal of the Scholarship of Teaching and Learning, Vol. 18, No. 4, December 2018.

josotl.indiana.edu 